
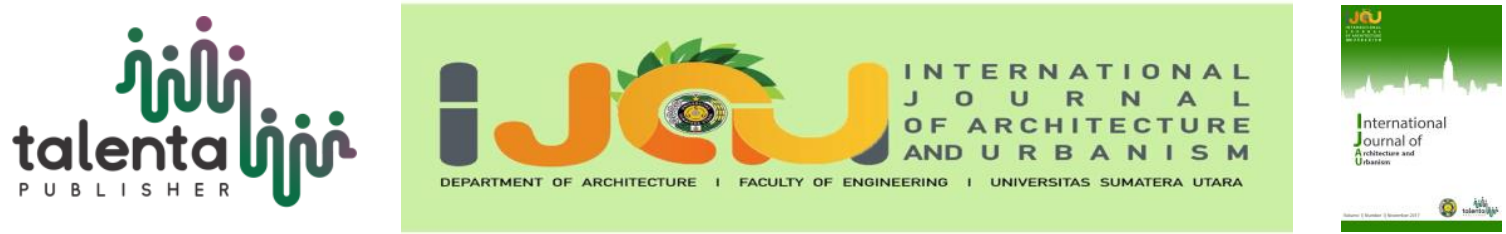

\title{
Designing Student Apartments With Green Building Concept on Ismail Harun Street
}

\author{
Dwira Nirfalini Aulia ${ }^{1^{*}}$, Nida Andini Putri Tanjung ${ }^{1}$ \\ ${ }^{I}$ Architecture Department, Faculty of Engineering, Universitas Sumatera Utara, Medan, Indonesia
}

\begin{abstract}
Apartments with green building concept are vertical dwellings that are built using the basic rules of green building namely energy efficiency and renewable energy, efficient use of air, use of environmentally friendly materials, use of waste and materials, improvement of good indoor air circulation, and sustainable development and smart growth. This concept is used as a fulfillment of housing needs for students around Universitas Negeri Medan, which is environmentally friendly. The concept of green building is expected to reduce household pollution generated from student apartments, which can reduce the quality of the surrounding environment and also reduce the costs of maintenance and operation of the apartment, which can have an impact on the quality of resident's life. In the process of designing this apartment, the writer uses a quantitativecorrelative approach to find what is needed by the apartment user. The process of designing an apartment with this concept will produce an environmentally friendly building that can save water use up to $53.28 \%$. This student apartment is equipped with a solar power plant that can save PLN electricity use by up to $33 \%$. Each apartment unit and room in the management office is also designed with natural light and natural air circulation in mind to reduce the use of electricity and air conditioning. This apartment also utilizes human waste by processing it into biogas using dome reactors.
\end{abstract}

Keywords: apartment, biogas treatment, green building, solar electricity, wastewater

\section{Introduction}

The apartment is a vertical housing that is usually built-in a high population area. In general, apartments are often found in big cities. Medan is one of the biggest city in Indonesia, but this city does not have much vertical housing like apartments. The city still has a bit of vertical housing, particularly apartments for students. The number of apartments built near the campus is still very small. Also, the development area is limited to an area and is not spread in several locations that have universities with a large number of students.

Based on data from the Ministry of Research, Technology, and Higher Education in 2017, on the recapitulation of the number of students in Medan City, there are two state universities, one state polytechnic, and more than 100 universities with a total of 280 thousand students [1]. The

\footnotetext{
*Corresponding author at: Architecture Department, Faculty of Engineering, Universitas Sumatera Utara, Jalan Perpustakaan Gedung J07, Medan 20155, Indonesia
}

E-mail address :dwira_aulia@yahoo.com 
number of students in Medan is the largest number on the island of Sumatra. Therefore, the market for residential homes for students in this city can develop quite well, as happened in Java.

Homes for students in Medan are mostly in the form of boarding houses and rented houses. Most boarding houses around of state universities in the city have rental rates ranging from Rp. 250,000 to Rp. 1,000,000.00 per month. Most of these boarding houses have limited facilities, ranging from bedroom without furniture to bedrooms with bathrooms in - rooms. Most boarding houses only have facilities for sleeping, without being equipped with supporting activities for student activities such as laundry, kitchen, minimarket, etc. Limitations of facilities provided by boarding houses can cause less effective time spent by students in meeting their daily needs.

Unlike the boarding house, student apartments are residential homes for students who have sufficient facilities to fulfill their daily needs. Apartment units generally have facilities for sleeping, eating, cooking, and washing in one place. Apartments also give a better level of privacy than boarding houses. Also, apartments provide public facilities such as retail, laundry, minimarkets, and others. These facilities will fulfill the residences' needs.

\section{Living with Green Building Concept}

Green building is a concept of environmentally friendly buildings that exist due to environmental problems this day. This concept is an answer to the global warming issue. Global warming is a process of increasing the earth's temperature due to the number of greenhouse gases in the atmosphere. The increase in the amount of gas that causes this greenhouse effect is caused by human activities that throw lots of greenhouse gases into the atmosphere. The concept of green building can reduce the amount of pollution and waste produced by humans starting from their homes.

In their daily life, humans produce pollution and household waste that comes from their daily activities. Also, many buildings do not pay attention to the long-term effects of materials in their homes, whether they are good for the environment and their health or not.

According to Barrows and Iannucci, a family will use 3.7-7 gallons of water for one toilet flushing, 8-14 gallons of water for washing dishes, and 45 gallons of water for washing clothes. This large amount of water will become waste and cannot be reused, so it must be disposed of in the city Riol. In addition to household waste, according to the World Health Organization (WHO), unhealthy air in the room is one of the causes of death with a greater percentage compared to outdoor air pollution. Also, many people still use building materials with Volatile Organic Compounds in it. This material can cause cancer if inhaled in the long term [2]. 
The concept of green building can be a solution to some of the problems above. This concept can reduce energy use because this green building concept implements waste management and renewable energy. Also, the application of the green building concept can reduce building maintenance costs. This concept will also create a healthy room by making efficiency in laying windows, proper insulation, and non-toxic materials. In the end, a healthy place to live will create healthy individuals physically and spiritually, which is needed by students who will become future generations.

\section{Literature Review}

According to Environmental Protection Agency of USA, green building is a practice of creating structures and using processes that are environmentally responsible and using energy efficiently through a building's life cycle, from analysis to design, construction, artistry, maintenance, renovation, and deconstruction where this practice develops and complements the classical building design that takes into account the economic side, utility, durability, and comfort [3].

Green building is designed as a whole to reduce the environmental impact on human health by efficient use of energy, water, and other resources, protect employee health and increase work productivity, and reducing waste, pollution and environmental degradation [3].

Green building has several benefits that cover from various sides, both from an environmental, economic, and social perspective. The benefits of Green building according to Environment Protection Agency of USA are improving and protect biodiversity and ecosystems, improving water and water quality, reducing waste flow, save and restore natural resources, reducing operating costs, creating markets for environmentally friendly products and services, increasing the productivity of residents, optimizing economic performance cycles, improving the comfort and health of residents, improving aesthetic quality, minimizing tension in local infrastructure, and the last is improving the overall quality of life [3].

According to Environment Protection Agency of the USA, in designing a green building, the components that has to be considered in the design are energy efficiency and renewable energy, water use efficiency, building materials and specifications that are more environmentally friendly, waste reduction, poison reduction, indoor air quality, and sustainable development and smart growth [3].

\section{Design Methodology}

In choosing the location of the property development of apartments, three criteria must be considered. These criteria include land use (existing land use), regulation of regional designation, as well as reach to the city center [4]. Land use in Deli Serdang Regency itself is arranged in the Spatial and Regional Planning (RTRW) of Deli Serdang 2010-2030 [5]. 
Since the apartment to be built takes the target of the student market, then the apartment will be built in the education area. According to the RTRW of the Deli Serdang District, the area belonging to the Education Area is PercutSei Tuan District [5].

Before determining the location of the design, some government rules must be considered. According to the Regulation of the Minister of Public Works No. 41 of 2008 concerning the location of residential development, there are specific criteria in determining the location of residential development, i.e., the location of residential development avoiding the use of technical rice fields, protected areas, and not in the boundary areas of rivers, beaches, water channel springs, railroads, and safe areas of flight [6].

In determining the location of the design, the apartment building has its characteristics. The selected location should consider the travel time to the activity center in a city. It takes 15 minutes.

Based on the theory above, the method that is used to choose the site is by looking at which location is on the educational area based on RTRW Deli Serdang. In this case, the education area of Deli Serdang district is only the Percut Sei Tuan sub-district, and the location closest to the campus and has an empty land area of over 10,000 $\mathrm{m} 2$ is on Jalan Ismail Harun. This location is located in front of Citra Land Bagya City residential, as in figure 1. It has a great view of Citra Land Bagya City's beautiful bridge.

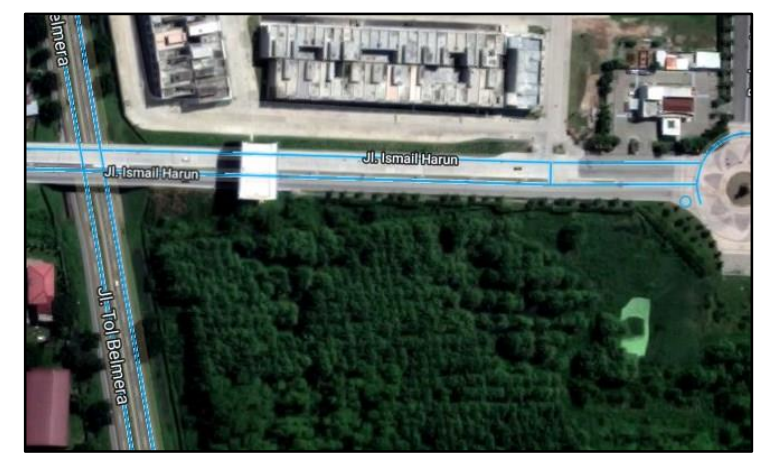

Figure 1. Location Map

Building's Design Methods

On designing this green building apartment, the author will use a quantitative-correlative analysis. The quantitative-correlative analysis is an analysis that looks at whether or not a replacement of research variables. In this method, there is a description of the problem with the supporting literature.

Quantitative analysis will use the descriptive method in analysis, processing, analysis, and presentation of some data. In contrast to qualitative analysis, this analysis will be done through site surveys to see what objects will be used. 
Through both analyzes, the data will be poured into a written paper. The written paper will contain problem identifications, data collecting, analysis, concept, design.

\section{Result and Discussion}

The basic concept of this apartment is to apply the conditions required of a building to be a green building. The apartment will have lots of windows and has a small tree as a barrier between the balcony of every apartment unit. Also, the building will implement biogas processing systems, WTP (Water Treatment Plan), and also the use of solar panels as one source of building electricity to make this building more efficient on energy use.

Building Space Requirements

This apartment has two types of housing units: studio type and two-bedroom type. Both types of houses are chosen to provide diversity so that users can choose which type can meet their needs. A comprehensive explanation of the building used for residential units can be seen in Table 1 .

Table 1. Area and Number of Residential Units

\begin{tabular}{ccc}
\hline Unit Type & Amount & Space needs \\
\hline Studio $\left(30 \mathrm{~m}^{2}\right)$ & 182 units & $5.824 \mathrm{~m}^{2}$ \\
\hline Two & 48 units & $3.072 \mathrm{~m}^{2}$ \\
bedrooms (48 & \\
$\left.\mathrm{m}^{2}\right)$ & \\
\hline Space needs (exclude corridor dan service \\
area)
\end{tabular}

\section{Outer Spatial Planning Concept}

The site's entrance will be placed on the north side of the site, which is located beside Ismail Harunstreet. This site will be fenced with an $80 \mathrm{~cm}$-height brick wall finished with slate stones. Site boundaries on the east, south, and west will be fenced by precast concrete walls with 3 meters height. This wall's inner side will be planted with a vine called Creeping ficus or commonly called a dollar leaf plant. CBT 65 razor wire will be placed on the top of the concrete wall to prevent people from entering the site by climbing.

The outer space consists of green space and apartment facilities such as futsal courts, swimming pools, and a mosque. This facility is arranged like a compass direction. On the northeast side, there is a futsal field. The southeast side is filled with waste recycling space, the southwest side is filled with swimming pools and lounges, while the northwest side is filled with a mosque. 
The location of the facilities provided on the outside side of the apartment building can be seen in figure 2 .

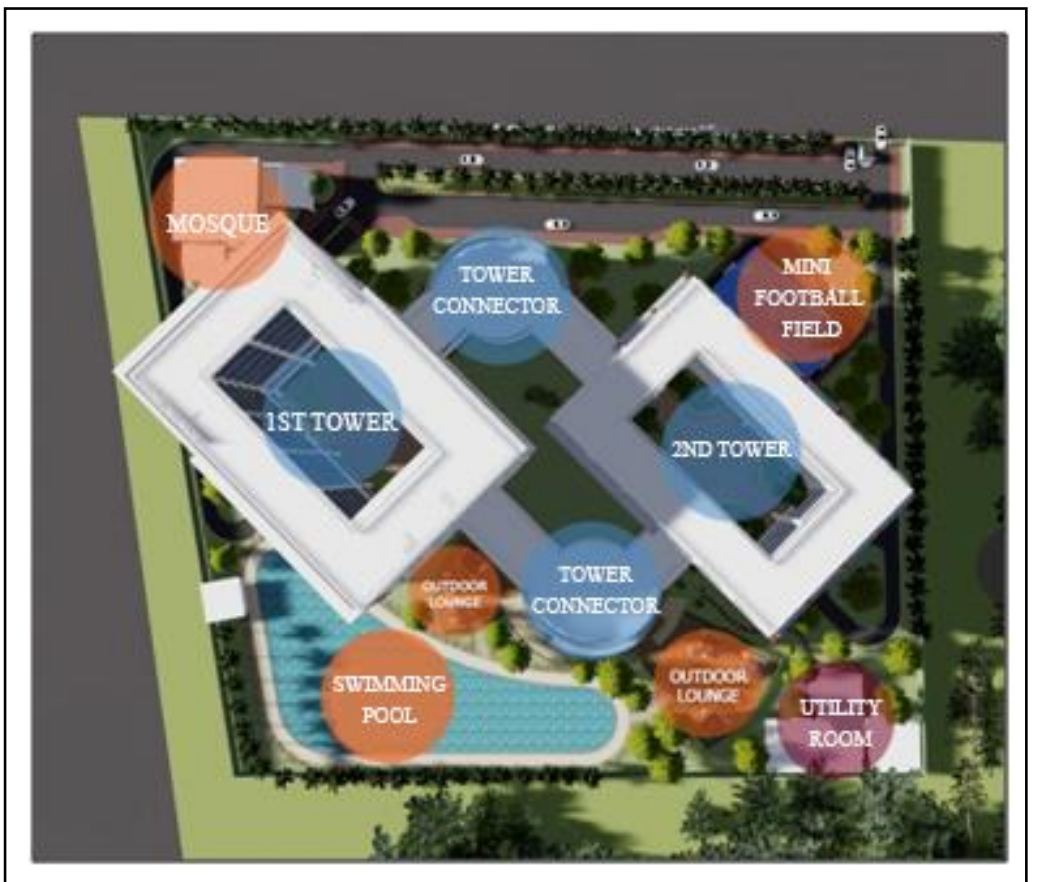

Figure 2. Siteplan

Some of the facilities can be used by the public. These facilities are mosques and futsal courts. Both of these facilities will be directly connected to the pedestrian line that connects the entrance and the lobby of the apartment. The pedestrian path is also found on the back of the apartment building that connects the lounge with a swimming pool and a special area for employees with utility rooms on the southeast side of the site.

\section{Inner Spatial Planning Concept}

This student apartment has a main building located in the middle of the site. The main building of this apartment consists of three parts: tower 1 , tower 2 , and connecting building. Tower 1 is a building consisting of a management office and studio type apartment units. Tower 2 is a building that has public facilities such as restaurants, cafes, and shops. In tower 2 , there are also two bedrooms-apartment units. Both towers are connected through connecting buildings, which are located on the north and south sides. In this connecting building, there are lobby and reception desk, pool lounge and lobby, gym, clinic, minimarket, and retail. Figure 3 will explain the zoning of the main building. 


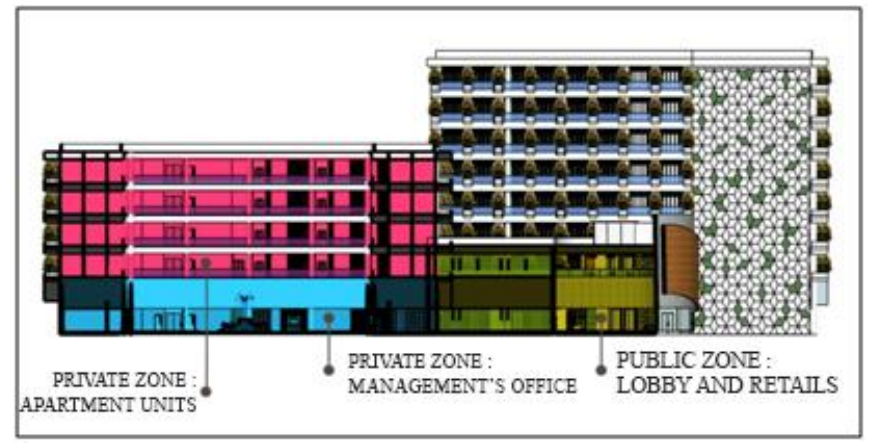

Figure 3. Zoning of the main building

This building has three inner courts that serve as the entrance to fresh air and sunlight into the room inside. The presence of the inner court is expected to facilitate the flow of air in every room inside the building. So that the use of air conditioning and lamps in the afternoon is reduced.

In figure 4, the apartment unit is located on the second floor. Apartment units are arranged in a single-loaded plan type. Each unit is mirrored, as shown in figure 4.

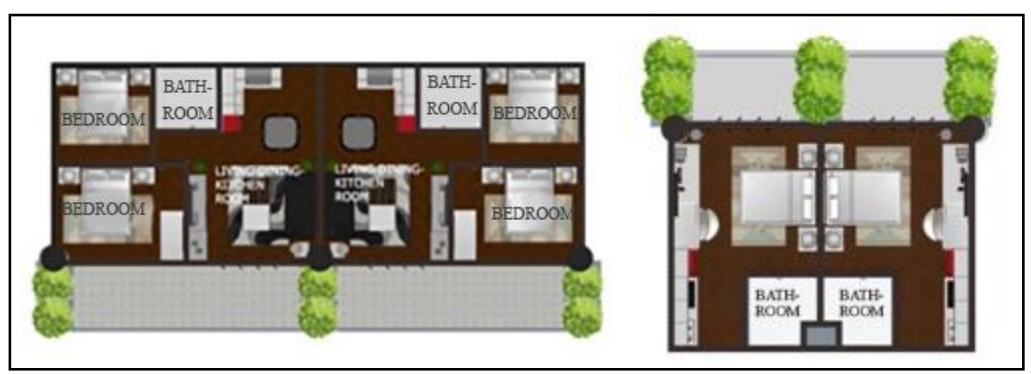

Figure 4. Studio type plan and two bedroom-apartment unit plan

\section{Building Mass and Façade Concept}

The building mass is formed from the basic form of space, which is a combination of block and cylinder. Two blocks are the basic form of apartment towers, while the connecting building has a cylindrical base shape. The shape of the beam in the tower section is taken to respond to the arrangement of the plan. In order not to be too rigid, the connecting building is formed cylindrically, so the building feels more dynamic. The process of mass formation can be seen in figure 5 . 


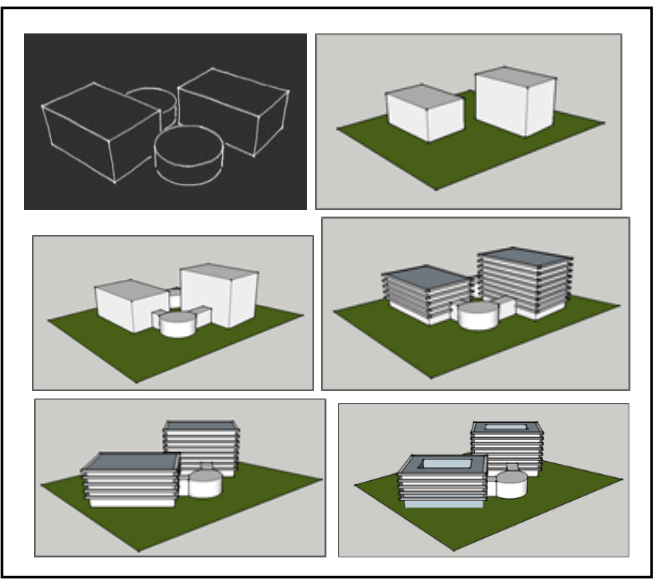

Figure 5. Building mass composition

The basic form will be changed according to the plan. Some mass will be added to the basic mass. This mass addition also refers to how the building responds to its environment. Some parts of the building will be pulled out. This section will be the balcony of each residential unit, as well as becoming a sun shading for the residential units below. The balcony side will have several advantages because there is a vertical jungle that gives some fresh impression to the building. The facade with a vertical jungle can be seen in the figure. Some parts of this building's façade will be filled with a concrete panel called a paper façade panel. The façade arrangement can be seen in figure 6 .

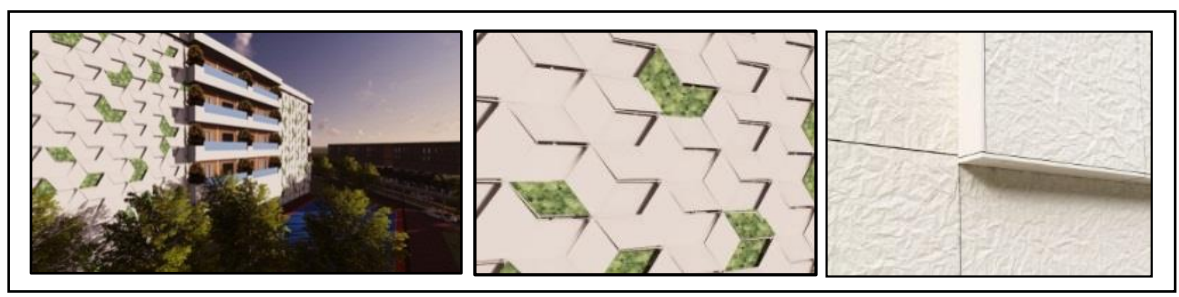

Figure 6. Vertical jungle, facade perspective, and the material's detail

The cylindrical connecting the building's façade inspired by the form of a wave. This form will be made from a rubber tree from the site. This cylindrical connecting the building's façade can be seen in figure 7 .

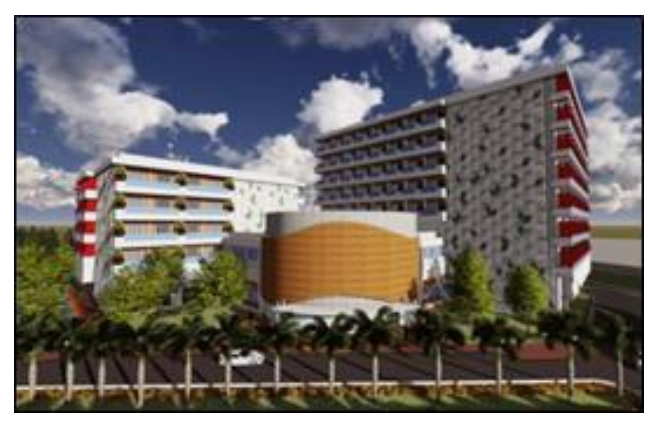

Figure 7. Connecting the building's façade and perspective 
Structure Concept

This building uses a rigid frame structure concept using $8 \times 8 \mathrm{~m}$ for the column module. The material which is used to support this structure is reinforced concrete. With a span of $8 \mathrm{~m}$, to make a strong look, this building will have a column with a diameter of $70 \mathrm{~cm}$, a beam with a width of $35 \mathrm{~cm}$, and a height of $70 \mathrm{~cm}$. This building column will have a cylindrical shape. This form is chosen to increase aesthetic value so that the building does not look too rigid. For foundations, this apartment will use a bore pile foundation. The supporting building's facade will be supported on the truss frame structure that is assembled on the bearing wall. For the concrete panel façade, it will be installed directly on the wall.

\section{Utility System Concept}

Clean water is a daily necessity for apartment users, both administrators, and residents of the apartment. The source of clean water for this building will come from PDAM and recycled water. To find the amount of clean water needed, some data is needed regarding the number of apartment users and supporting facilities. Table 2 will explain daily clean water needs data.

Table 2. Clean Water Daily Needs

\begin{tabular}{llll}
\hline \multicolumn{1}{c}{ Function } & Unit & Users quantity & \multicolumn{1}{c}{ Clean water needs } \\
\hline Apartment & People & 364 people & $180 \mathrm{~L} /$ day x 364 people $=65.520 \mathrm{~L} /$ day \\
\hline Office & People & 256 people & $60 \mathrm{~L} /$ day x 192 people $=15.360 \mathrm{~L} /$ day \\
\hline Restaurant & Seats & 64 seats & $70 \mathrm{~L} /$ day x 64 people $=4.480 \mathrm{~L} /$ day \\
\hline Total of Clean Water Needs & & $81.520 \mathrm{~L} /$ day \\
\hline
\end{tabular}

Source: Juwana, 2005

Besides, the apartment will need clean water for extinguishing if the building is caught on fire. The amount of water needed is 520,020 L for sprinklers and 792,000 L for hydrants. The amount of clean water needed in the building is $1,393,540 \mathrm{~L}$.

This apartment will use a Wastewater Treatment Plant (WTP). This aims to reduce the use of water from PDAM and utilize the building's wastewater to become clean water that can be reused.

The average ratio of wastewater usage discharges to the discharge of clean water usage in an apartment is $80 \%$. These results can be used as the basis for determining the amount of wastewater produced by the building per day. According to it, the amount of wastewater produced by the building is $65.216 \mathrm{~L}$. 
This wastewater consists of $74 \%$ gray water and $26 \%$ black water. Gray water will go through the management process at WTP. the amount of water that will be processed through WTP is 48.259,84 L [7]. The wastewater, through the process of the WTP system, will experience shrinkage of $10 \%$. The amount of clean water obtained from the wastewater treatment process is $43.433,856 \mathrm{~L}$. This recycled water will be used for flushing toilets in the apartment. This system will save water usage up to $53,28 \%$

Blackwater is the main ingredient that will be used to produce biogas. Biogas will later become the fuel used by apartment residents for cooking. Because the main ingredient in making biogas is human waste, the amount of biogas composition that will be processed on this biogas installation is $186 \mathrm{~kg} /$ day depends on how many people live in this apartment.

To produce more amount of biogas, the biogas reactor used is a dome reactor where, through this reactor, the amount of biogas produced is $45.72 \mathrm{~L} / \mathrm{kg}$ of human waste. Based on this amount, $8.503,92 \mathrm{~L} /$ day of biogas will be produced. The amount of biogas produced daily is insufficient to fulfill the daily needs of all apartment residents because this building needs 41,54 $\mathrm{m} 3 /$ day just to fulfill the residents' needs. Due to the insufficient, the biogas that is produced by the dome reactor will be used for restaurants and retails.

To reduce the use of PLN electricity, this building will be equipped with Rooftop Off-Grid Solar Panel technology with the polycrystalline solar panel. This type is more efficient when used on a site that has a tropical climate [8]. Table 3 will show the number of electrical/load to be borne by the solar power system of the apartment.

Table 3. Table of Electric Loads for Building From Lighting

\begin{tabular}{|c|c|c|c|c|}
\hline Equipment & Amount & Power & Duration & Total Power (on kWh) \\
\hline LED 18 Watt & 1027 pcs & 18.486 Watt & $12 \mathrm{hr}$ & $221.832 \mathrm{Wh}$ \\
\hline TL 61 Watt & $\begin{array}{c}266 \mathrm{pcs} \\
6 \mathrm{pcs} \\
5 \mathrm{pcs} \\
1 \mathrm{pcs} \\
\end{array}$ & $\begin{array}{c}\text { 16.226 Watt } \\
366 \text { Watt } \\
305 \text { Watt } \\
\text { 61 Watt } \\
\end{array}$ & $\begin{array}{c}24 \mathrm{hr} \\
16 \mathrm{hr} \\
12 \mathrm{hr} \\
6 \mathrm{hr} \\
\end{array}$ & 399.306 Wh \\
\hline LED 10 Watt & $11 \mathrm{pcs}$ & 110 Watt & $12 \mathrm{hr}$ & $1.320 \mathrm{Wh}$ \\
\hline LED 5 Watt & $\begin{array}{l}92 \mathrm{pcs} \\
42 \mathrm{pcs}\end{array}$ & $\begin{array}{l}460 \text { Watt } \\
210 \text { Watt }\end{array}$ & $\begin{array}{l}12 \mathrm{hr} \\
24 \mathrm{hr}\end{array}$ & $10.560 \mathrm{Wh}$ \\
\hline LED 2 Watt & 15 pcs & 30 Watt & $12 \mathrm{hr}$ & $360 \mathrm{Wh}$ \\
\hline \multicolumn{4}{|c|}{ Total power for lighting needs } & $633.378 \mathrm{Wh}$ \\
\hline
\end{tabular}

Source: Author's Analysis

The total daily electrical power that will be covered by the solar power system is the amount of power used for lighting, and the power used for the socket is $760.053 \mathrm{Wh}$. The number of solar panels needed to cover daily power is 921 panels. 
This panel will be arranged in series. One circuit consists of ten panels, and four circuits will be parallelized into a more complex circuit. This circuit will be incorporated into the inverter, which functions as a currency converter. The inverter used is a $20 \mathrm{~kW}$ inverter. Some of the power generated from this circuit will be channeled into a deep cycle battery with $12 \mathrm{~V} 230 \mathrm{Ah}$ specifications and has a 40\% DOD. This building will need 689 batteries, which are arranged in series.

To fulfill the daily electricity needs of all apartment units, this building needs $1,105,064 \mathrm{Wh}$, and to fulfill the electricity needs of this building requires $1,865,117 \mathrm{Wh}$. By using a solar power generation system, this building can save electricity usage of up to $33 \%$.

The apartment will be equipped with a telephone network. This telephone network can also be used for internet connections.

In this building, two drainage systems will be applied. They are drainage to drain rainwater and drainage to drain waste to the Wastewater Treatment Plant. In this apartment building, drainage to drain wastewater to the WTP does not use culverts but uses pipes only. This is due to the basement in the building, so that it is impossible to use culverts. However, to drain rainwater, this building will use a side ditch system with concrete material with a sewer.

This building will use split air conditioners in every room that needs air conditioning. To cool the air naturally, some parts of the front and rear sides of the room are replaced with a roster so that the airflow in the room remains smooth.

In anticipation of fire disasters, this building will be equipped with emergency stairs, hydrant boxes, sprinklers, smoke and heat detectors, as well as light fire extinguishers (LFE). Hydrant Box, Manual Call Point, Bell Alarm, and LFE will be placed on 6 points that are easily seen on each floor of the apartment. Each tower will be equipped with two emergency ladders so that it is more accessible when a fire occurs.

Sprinklers, heat detectors, and smoke detectors will be placed along the corridor with a distance of 4 meters. Each room will also be equipped with a sprinkler, heat detector, and smoke detector.

\section{Conclusion}

Student apartments are built considering the requirements of a green building. To fulfill these requirements, this apartment will have three inner courts to utilize sunlight as natural lighting of the room inside the building. This inner courts also facilitate air circulation in every room. This student apartment is equipped with a solar power generation system that can save electricity usage from PLN up to 33\%. The application of STP technology in buildings also saves water 
usage by up to $53.28 \%$. The amount of waste discharged into the city Riol is also reduced due to the STP. The utilization of black water waste is used as biogas fuel. It also reduces building maintenance costs because the gas and management requirements for managers' and retailers' needs for gas are fulfilled through this system.

The problem of air circulation in the room can also be overcome by using the roster wall in each room. The application of the vertical jungle concept to buildings is also used to improve the air quality in each apartment unit. Non VOC materials such as wall paint reduce toxins in each room. Every room also does not use PVC material, so it is more environment-friendly.

\section{Acknowledgment}

This article was written by the researcher who studied at the University of Sumatera Utara and was given out as a donation to the government to preserve and improve the value of design and technology.

\section{REFERENCES}

[1]Rekap Jumlah Mahasiswa Provinsi Sumatera Utara. (n.d.). Retrieved from https://forlap.ristekdikti.go.id/

[2]Barrows, J., \& Iannucci, L. (2009). The Complete Idiot's Guide To Green Building and Remodelling. Indianapolis, USA: Penguin Group.Indonesia,

[3] United States, E. (n.d.). Basic Information : Definition of Green Building. Retrieved from https://archive.epa.gov/greenbuilding/web/html/about.html

[4] Amanullah, M. S., \& Haryanto, R. (2017). Pemilihan Lokasi Terbaik Pengembangan Properti Apartemen Di Perkotaan Cibinong Raya Kabupaten Bogor. Pemilihan Lokasi Terbaik Pengembangan Properti Apartemen Di Perkotaan Cibinong Raya Kabupaten Bogor,5(Jurnal Pengembangan Kota), 1st ser., 93-103.

[5]Peraturan Daerah Kabupaten Deli Serdang, Rencana Tata Ruang Wilayah Kabupaten Deli Serdang Tahun 2010 - 2030 (2010).

[6] Menteri Pekerjaan Umum Republik Indonesia. (2008). Peraturan Menteri Pekerjaan Umum Nomor : 41 /Prt/M/2007 Tentang Pedoman Kriteria Teknis Kawasan Budi Daya (p. 26). Jakarta, Indonesia.

[7] Affiandi, J., Pharmawati, K., \& Nurprabowo, A. (2016). Perencanaan Sistem Instalasi Plambing Air Bersih Gedung Hotel Tebu. Perencanaan Sistem Instalasi Plambing Air Bersih Gedung Hotel Tebu,4(Jurnal Rekayasa Lingkungan), 2nd ser.

[8]Hakim, M. F. (2017). Perancangan Rooftop Off Grid Solar Panel Pada Rumah Tinggal Sebagai Alternatif Sumber Energi Listrik. Perancangan Rooftop Off Grid Solar Panel Pada Rumah Tinggal Sebagai Alternatif Sumber Energi Listrik,8(Jurusan Teknik Elektro), 1st ser. 